Mapping Affect Studies

Mapeando los Estudios del Afecto

Ali Lara

University of East London; alara@uel.ac.uk

\begin{tabular}{|c|c|}
\hline & Abstract \\
\hline $\begin{array}{l}\text { Keywords } \\
\text { Ontology } \\
\text { Methodology } \\
\text { Epistemology } \\
\text { Politics } \\
\text { Affect studies }\end{array}$ & $\begin{array}{l}\text { This editorial for the special issue Mapping Affect Studies, I briefly introduce the } \\
\text { relevance to explore the intersections between affect studies and other relevant } \\
\text { fields for social sciences and humanities. To create a frame to explore such inter- } \\
\text { sections, I explore the affective turn in relation to its epistemological/ontological } \\
\text { assumptions, its methodological challenges, and the politics of the affective turn. } \\
\text { Then, I offer some notes on two intersections with fields that are missing in this } \\
\text { Special issue: the intersection between affect and feminism, and affect and disabil- } \\
\text { ity. I finish this introduction by presenting the articles of the special issue. } \\
\text { Resumen }\end{array}$ \\
\hline $\begin{array}{l}\text { Palabras clave } \\
\text { Ontologia } \\
\text { Epistemologia } \\
\text { Metodología } \\
\text { Política } \\
\text { Estudios del Afecto }\end{array}$ & $\begin{array}{l}\text { En esta nota editorial del número especial Mapeando los Estudios del Afecto intro- } \\
\text { duzco brevemente la relevancia de explorar las intersecciones entre los estudios } \\
\text { del afecto y otros campos relevantes de las ciencias sociales y las humanidades. } \\
\text { Para crear un marco de exploración de dichas intersecciones, exploro el giro afec- } \\
\text { tivo en relación a sus implicaciones epistemologicas/ontologica, sus retos metodo- } \\
\text { lógicos, y las políticas del giro afectivo. Después, ofrezco algunas notas sobre dos } \\
\text { intersecciones que están ausentes en este número especial: la intersección entre el } \\
\text { afecto y el feminismo y entre el afecto y los estudios de la discapacidad. Termino } \\
\text { la introducción presentando los artículos que no forman este número especial. }\end{array}$ \\
\hline
\end{tabular}

Lara, Ali (2020). Mapping Affect Studies. Athenea Digital, 20(2), e2812. https://doi.org/10.5565/rev/athenea.2812

Let's map affect. For a simple reason, to know how to go to the places we want to go. Or even better, to see where else could we go that we have not been yet. What kind of places are out there that we might not even be aware of and what domains are still to be explored? Some fields in the social sciences are quite old, we've been dwelling in and messing around them for years so everybody knows what you can get if we go there. That is not the case for affect studies, there is still a lot to be explored here. However, affect is by no means new, there's been around twenty years of contributions to understand the non-conscious processes involved in social life as explained by cultural studies/critical theory, and far way more if we think about affect as broadly as it's understood in philosophical and psychoanalytic approaches. But let's stay with the contemporary affective turn, and the expansion that such a field of studies has experienced in recent years.

In some academic contexts, it is still a common idea that while Affect Studies offer an interesting contribution, they are not really something you can use to understand or to further advance the fields that you care about. This is true especially for young scholars or $\mathrm{PhD}$ students that have not been trained (and nobody has) in affect 
studies. While affect sounds interesting, people always ask: "Sure, but how can I use this theory to do research on injustice against women?", or, "Cool, but then what methodology do they use?". As always happens in social sciences, new theories take a while to come down to the realm of the mortals and be accessible to us so we can use them and work with them. I have decided to call this Special Issue "Mapping Affect Studies", because it is my intention to deliver a comprehensive set of articulations between affect studies and some of the main fields of interest for the social sciences and humanities. So, the reader can see how it has been used, what kind of studies you can develop, and what remains to be looked at. Thus, this special issue is made of articles exploring literature that connects affect with fields like queer studies, race studies, labor studies, neurosciences and cognition, and art and literature. But before going into each of the marvellous articles within this special issue let's talk about affect theory in general. Before we move forward let's try to make clear three questions that you might be wondering about affect. First, the turn from epistemology to ontology; second, the methodological implications; and third, the approach of affect studies to politics and subjectivity.

A little bit of a warning before we move on, while literature in the social sciences is produced in countless languages, the body of literature that shapes affect studies has mostly been produced in English-speaking academia. We have decided to publish this special issue simultaneously in Spanish and English following the democratic vein of our host journal Athenea Digital-as widely demonstrated by its Open Access policies. It comes as no surprise that we choose Athenea Digital to publish this Mapping of Affect Studies, after all, this journal was one of the first spaces to be open to publishing research on affect in spanish-speaking academia (see Enciso \& Lara 2014; Lara \& Enciso 2013). Thus, if the literature reviewed here is mostly from USA, UK and Australia, the intention of offering a bilingual mapping is to start a dialog with academia in the Spanish-speaking world as well as to further clarify the realm of affect studies specially for young scholars. Ok, let's move on, let's go mapping affect:

\section{From Epistemology to Ontology}

According to John Cromby, we can summarize the contribution of Affect Studies in two main points "First, affect theorists usefully emphasize the deliberate or incidental manipulation of material intensities, vibrations or frequencies (which are, most proximally, at their point of impact upon the living body, physiologically transduced)." (Cromby, 2015, p. 121) This means that the things that happen inside our bodies and other material interactions could be (and are) affected from a distance, and that this process makes populations-not subjects-that in turn become the target of control 
mechanisms. "Second, affect theorists usefully emphasize the ways that feelings can instantiate in the present the influence of the indeterminate future" (Cromby, 2015, p. 121). This means that affective responses could be (and are) stimulated based on the indeterminacy of events that have not happened yet. For example, when fear is evoked given the probability of a terrorist attack that is still to happen, and yet it already has an effect in the present: we are afraid. This has made manifest the non-linear temporality of affect and reconfigured our understanding of the effect of public policies or technologically mediated augmentation. But how did we get here?

It is well known that every self-proclaimed "turn" in the social sciences argues to represent the one and definitive change that we were all looking for and that can solve all our problems. Well, I'm definitely not going to argue that this is the case for affect studies; as approaches to affect shed light over some things and that necessarily means stopping shedding light over other things. However, in order to understand the theoretical gesture of this "turn" as well as the contributions that Cromby points to, it is worth clarifying a couple of things about the displacement of attention in knowledge production from epistemology to ontology. This is also going to be helpful to clarify how affect studies work different to critical approaches based in poststructuralism.

Affect studies started as a project to look for what lies beyond/before/outside representation, language and conscious activity-either individual-like cognition or collective-like social agreements. Attention to this already-processed reality was certainly the focus of social scientific research based in poststructuralism during 20th century. Affect rose up as a theoretical movement against the privilege of language, and it was such a privilege that was equated with epistemology. To say that previous research was focused on epistemology, is to say that it's central concern was the ways in which we human beings access (or make) reality-the experience, the sense-making, the socially constructed, etc.--such that the only thing left for social scientists was to try and represent that access of the reality in as accurate a way as possible. Thus, knowledge production was doubly epistemological. First concerned by how we-humans-access reality, then concerned by how we-scientists-access the way in which we-humans-access reality. Like a dog chasing its own tail. In this sense critical approaches share with Positivism the obsession with understandings of reality that are empirically grounded and evidence-based. No wonder we spend so much time learning methods to collect and analyze data to represent the way in which the world has already been represented! By the way, this theoretical gesture has been baptized in recent philosophical debates within the continental tradition as the problem of correlationism (Meillassoux, 2012), according to which reality doesn't exist outside our representation of it. As has been well documented, privileging language and representa- 
tion brought as a consequence the systematic forgetting of the human body and all kind of materiality (see for example Clough, 2004). Thus, in order to escape this epistemological regime of knowledge production, affect studies turned attention to the body, and to those processes that precede/exceed conscious activity, individuality, and of course discourse and meaning-making. As soon as we turned back to the body, we also had to turn back to science (see Lara \& Enciso, 2014) and to look for a new philosophical matrix able to support theoretical contributions about a processual body that was constantly becoming something else, so we chose the process philosophies from continental tradition (see Lara, 2015). If we were going to abandon discourse and look for pre-conscious and pre-individual processes, we were going to need new tools. It follows that the focus of attention was no longer the representation of reality, but rather reality without representation. This is what it means to abandon epistemologically-centered knowledge production towards an ontological focus. It means to look at what reality and particularly bodies are doing regardless of, before, besides, beyond, and despite being represented. Affect studies took as a priority an interest in the capacities of bodies or following Spinoza: what a body can do.

All this is already an old story. But it is important to be clear about this movement-from epistemology to ontology-as it is the origin of the methodological challenges (or accusations) faced by affect studies as well as of the expansion of the political agenda in social sciences and the approaches to subjectivity production that we will explore in a minute. After all, knowing, as Cromby suggests, that the capacities of our bodies can be altered expands our political concerns beyond the ideological or discursive mechanisms of power. In a similar way, knowing that thought and emotions might be inserted without the corresponding external stimuli, necessarily brings us to reconsider how the production of subjectivity works, and even more, to reconsider the sovereign status of the subject in contemporary capitalism. And of course, getting all this done represents a few methodological challenges, to say the least.

\section{Affect and Method}

One of the most common questions when it comes to affect studies is the methodological one. What is the method of affect theory? How do they collect empirical data? How do they analyze such data? What is the recipe? Sorry if it's disappointing, but there is no such a thing. Affect is infra-empirical, Patricia Clough (2009) claims, that means that affect refers to a capacity that has not yet been manifested. When affect has been captured and passed to be expressed in the phenomenological realm from which we collect our empirical data, it has already become something else. When affect becomes behavior that you can describe, when it becomes words that you can 
transcribe and analyze, when it turns into personal experience that you can hear or tell, or an idea that you can express, we are no longer in the presence of affect, we are now dealing with behavior, discourse, reported-experience, and cognizant ideas. So, you cannot catch it. In a special Issue for the Graduate Journal of Social Sciences, Matthew Bakko and Sibille Meraz have thrown this question in this way:

What can affect offer to the social sciences when affect, and the world it brings about, escapes representation and consciousness? In other words, given that affect is often framed as a phenomenon that, at least partially, escapes perceptions, knowledge, reason, and language, how can it be made a focus of empirical research efforts? Isn't affect precisely that which, per definition, cannot be captured through existing modes of knowledge production and representation? $(2015$, p. 8$)$

Therefore, if there is a way to produce an empirically grounded research informed by affect theories, it's going to look very different to what we are used to in the socalled critical approaches. Patricia explains it this way:

Any method of attending to affect will profoundly unsettle any conception of method as being in the control of human agency or human consciousness inhering in the human subject (...) Any method of attending to affect cannot simply be a matter of containment; it also cannot simply be a matter of interpretation, meaning, signification or representation. (Clough, 2009, p. 49)

But not everything is lost for the lovers of the empirical. Despite the apparent impossibility to systematize the production and analysis of empirical data about affect, there are some attempts to be considered as sort of methodological guidelines-not recipes. According to Britta Knudsen and Carsten Stage (2015), it is possible to develop an "empirical grounded affect research". To do so, they argue, the researcher needs to be aware of at least three main challenges to be faced: asking research questions about affect, collecting and/or producing embodied data, and tracing affects empirically. Whereas they recognize the multiple challenges within this agenda, they focus on three strategies to deal with the second challenge in particular, the production of embodied data. In order to produce this kind of data, they offer three meta-strategies that could be used as methodological guidelines to develop empirical analyses concerned with affect. The first one is the creation of "inventive experiments", either in controlled or everyday environments they suggest to "intervene in social life by offering certain forms of controlled sensual stimulation staging particular epistemic and aesthetic events in order for the researcher to see Affective liveliness unfold and open up to what exceeds current understandings" (p. 10). The second strategy is called "embodying fieldwork" and refers to a change from the traditional focus of attention to- 
ward different techniques used in field work-rather than collecting representations or mere descriptions, researchers could "investigate more-than representational layers and emotional/affective practices embodied by informants" (p. 11). And the final metastrategy, "the collection/production of Affective textualities" that can be "either produced in the heat of affective experience or while remembering or recollecting them via textual production" (p. 12). It is very important to point to the fact that these strategies to produce embodied data work only to facilitate the "tracing" of affect in the empirical material. An intense experience resulting from an experimental technique, and the pictures, videos, narratives, or otherwise that you could produce from it are not affect but they carry the history of an Affective encounter and can be used to 'trace' Affect.

A theoretical approach commonly in dialogue with affect studies is non-representational theory (Thrift, 2007) with a corresponding methodological approach typically known as non-representational Methodologies (Vannini, 2015). According to Philip Vannini a non-representational and yet empirical approach should be characterized by its interest in five different subject matters: events, relations, doings (practices and performances), affective resonance, and backgrounds. The idea of these five objects resonates with Knudsen and Stage's proposition for 'tracing' affect in the empirical, as long as non-representational methodologies suggest that "these five forces reverberate across the lifeworld, informing and shaping each other, unfolding in more intricate patterns as new research directions are revealed, inspiring non-representational analysis and rendition" (Vannini, 2015, p. 9). While the non-representational people argue that events, relations, doings, resonances, and backgrounds represent the what of the method, the object to look at, non-representational methodologies propose that the how of the analysis should remain a matter of "style", particularly writing style for the presentation of the analysis. In opposition to the traditionally scientific methodological agenda of description and explanation, affect and non-representational methods would side for an approach dwelling in the middle of description and speculation.

This preoccupation with writing style as method in affect studies is not exclusively that of non-representational folks, authors like Anna Gibbs (2002) Patricia Clough (2009) Karen Barad (2014) and myself $(2017,2018)$ have suggested that the use of experimental writing and even poetry hold great promises to increase and direct the capacity for speculation about the infra-empirical realm. To put it in different words, what you cannot see and analyze is left for imagination to play with. But be careful here, speculation doesn't mean spouting nonsense, the very reason affect stud- 
ies are strongly based on process philosophies is because they offer systems of speculation that allow us to theorize about the non-empirical.

Despite the variety of efforts within affect studies, most authors (myself included) would agree that the intention is not to develop a universal method, but rather to keep the methodological sphere open for the continuous expansion of the field. In the recently appeared first Affect Studies Journal, Capacious, the editor, Gregory Seigworth, put it this way:

If Affect study is to be Capacious (as I have maintained it must be) then it cannot be close down (as outlined above) around any specific disciplinary route or explicit set of step-by-step-step methods, or cleanly-scrubbed concept-clusters or rote performance gestures. Cast a wary eye upon anyone who tells you that they have located the one way that critical attention to affect should be pursued. (Seigworth, 2017, p. iv)

This is simultaneously one of the scariest and nicest things about affect studies (and other contemporary movements) that knowledge production is again open to creativity and imagination.

\section{Affect, Politics and Subjectivity}

Let's recap a bit, so affect is more concerned with ontology than epistemology and therefore it doesn't have a fixed method. But the epistemological and methodological obsessions of poststructuralism and the critical approaches that emerged from it were there for a reason. The political spirit behind social theory in the second half of 20th century is perhaps the best inheritance we got from these traditions, and the focus on the empirical had to do precisely with demonstrating and evidencing issues that needed to be pointed out, as well as the ways in which these issues shaped the subjects we were. This hasn't changed. The world is still like that. However, when it comes to affect another common issue is the alleged inconsistency between the agenda of social sciences and affect studies. In social sciences we are concerned about understanding social processes that structure our lives and determine the conditions we live under, and what is more, we are particularly interested in describing, analyzing, and denouncing the social formations that produce living conditions full of inequality, injustice, and all forms of domination. And what is more, we are fully interested in what kind of subject emerges out of those living conditions and how such subjects are being produced. It comes as no surprise that gender, race, disability and class emerged as huge fields of interest in critical approaches. In sum, it is safe to say that two main concerns for social sciences are our political agenda and our concerns for subjectivity. 
And this is precisely the two main critiques that affect studies had received along the first ten years of 21st century.

For example, Margaret Wetherell explicitly bemoans this loss in determining that much of affect theory "rest(s) on a kind of anti-humanist negation of subjectivity... (where) subjectivity becomes a no-place or waiting room, through which affect as autonomous lines of force pass on their way to something else" (2012, p. 123). For her and other critics, this move threatened a centering of forces that, while impacting people, could not be traced in any meaningful way to their conscious (or unconscious) actions (Ellis \&Tucker, 2015). Affect studies' interest in pre-conscious events was accused to be an attempt to replace subjectivity as one of the main concerns of social sciences, and that quickly led to the critique that affect studies is a field that diminishes attention to issues of injustice and domination, especially when such were related to minority groups whose identities in terms of class, gender, race, and disability completely escaped the original concerns of affect studies. Ruth Leys has recently elaborated this critique in terms of a lack of attention to intentionality, in her words:

Just so, we might put what is at stake for the theorists whose turn to affect I have been analyzing is a "logic" according to which attention to ideology or belief is replaced by focus on bodily affects that are understood to be the outcome of subliminal, autonomic corporeal processes. Stressing bodies over ideas, affect over reason, the new affect theorists claim that what is crucial is not your beliefs and intentions but the Affective processes that are said to produce them, with the result that political change becomes a matter not of persuading other of the truth of your ideas but of producing new ontologies or "becomings", new bodies, and new lives. (Leys, 2017, p. 343)

Elsewhere some friends and I have developed an argument that is different to the Leys' one (Lara et al., 2017), explaining that affect studies keeps the historical interest of social sciences in the production of subjectivity but its manifested in a different way. The approaches developed within affect studies are interested in the production of subjectivity that emerges out of events and forces beyond, below, above and bypassing conscious activity and reached out by other means than discursively mediated interactions. Affect studies don't deny the relevance of discourse, ideology, or any kind of subjectivity production mediated by conscious activity; they just want to theorize other cases that remain to be explored. Recently, I wrote something with my friend Antar that is going to be useful to illustrate this kind of affective approach to the study of subjectivity. We spent some time looking at how an App called Happify, which is based in Positive Psychology, trains the bodies of the user by inserting them in a program that is supposed to make them happier. As part of this training program the user creates habits that eventually modify the capacities of the bodies to respond 
and ultimately to feel certain emotions and alters the rhythm of some specific organic functions like breathing or the heart rate. Out of this reconfiguration of the body a new subject emerges, a subject that always knows what it is feeling and how to proceed about it (Martinez \& Lara, 2019). This is the kind of subjectivity production that affect studies are interested in, one that is not mediated by relations of power in the traditional sense, but that results out of the modification of the capacities of the bodies. As Amit Rai explains, in affect studies, the modification of this body's capacities is understood to occur

In feedback loops with natural, technological, and social ecologies. This has allowed for a non-linear dynamical approach to media ecologies that would allow for contingency, chance, and transformation as well as a clearheaded analysis of forms of power that operate through the ecologies themselves. (Rai, 2018, p. 72)

As you can see, affect is totally about subjectivity and highly political.

Talking about the political, it is important to say that affect studies has never abandoned the political concerns of the social sciences, it has rather realized about new forms of control and domination that instantiate affective processes in human bodies by means of assemblages, distance-driven forces, or public policies that target human affective states. Patricia Clough (2018) argues that the target of control societies is not the individual organism but populations. Well, affect studies have theorized how affect is targeted in these populations by means of preemptive power and temporality manipulation (Massumi, 2015) or political assemblages operating in natural disasters like hurricane Katrina (Protevi, 2009), the deliberate production of disabled bodies in war zones (Puar, 2017), or the mnemonic control exercised by means of publicity (Parisi \& Goodman, 2011) to give just some examples. Once again, whereas politics of intersectionality and identity production, or ideological manipulation are still ongoing processes in the contemporary world, technology and new policies have opened up new possibilities for control of populations, the contributions of affect studies to the political agenda of social sciences are right there.

Elsewhere, some of the authors appearing in this special issue have argued that both critiques commonly attributed to affect studies, namely, the lack of concern for subjectivity and the lack of a political dimension, are in fact one and the same critique: "a critique of the lack of politics of the sovereign subject qua a conscious, self-contained organism of free will” (Lara et al., 2017, p. 34). This is how a turn from epistemology to ontology expands the understanding of subjectivity production and politics of control: by including in the analysis of social life events escaping consciousness and then looking at how these events are used to control populations as well as how those 
events participate in the shaping of conscious activity and subjectivity production. Of course the fact that contemporary capitalism increases conditions for injustice and inequalities mustn't ever be minimized, but, in times of affect, we believe that:

How certain subjects affect and are affected is not a random process, but demands theorization toward the level of population, toward how affect moves through or gets 'stuck' to certain bodies-in-formation and that also participates in creating subjectivities across various political contexts, or what has recently been called 'Affective Capitalism'. (Lara et al., 2017, p. 34)

Thus, affect studies provide a body of literature that can and should be put at the service of contemporary issues of injustice, inequality, domination, and subjectivity production. The advantage of doing this with affect is that it has theoretical tools useful for dealing with new forms of injustice mobilized by new technologies or policies characteristic of the latest neoliberal capitalism.

\section{Two unforgivable absences}

Before I say nothing about the content of the articles contained in this special issue, I want to make some notes about absences that shouldn't be here, but unfortunately, they are. I'm talking about the intersection of affect and feminist studies as well as affect and disability studies. There is a lot of other fields, but we can't neglect the relevance of feminist and disability studies in the contemporary landscape of social theory and social sciences, as well as their relevance in the current political moment. This special issue is in great debt to these two fields, so even when we don't have the articles exploring these intersections, I want to offer some basic coordinates for those interested in such fields.

Feminism first. The relationship between affect and feminism has been a complicated one, in part because it's been precisely feminist scholars that historically have pointed out the absence of the body and the emotional sphere of life in the production of knowledge-and they did this way before affect appeared. In this regard, some feminist scholars remain suspicious of the turn to ontology involved in the affective turn, because that neglects somehow, or moves the attention from, the epistemological concern on relations of affect/emotion-knowledge-power that have been central for feminist theory. Anu Koivunen even claims that "to talk about an Affective Turn is, to an extent, to ignore generations of feminist scholarship on articulating subjective and social experience of injustice" (Koivunen, 2010, p. 22). Evidence supporting this claim could be found in Clara Fisher (2016) who offers a feminist genealogy of affect to show that 'at least from second wave feminism' emotions, affects, and feelings have been at 
the centre of feminist concerns. This is very important because, as Sara Ahmed (2015) notices, even if feminist and queer work is acknowledged as a precursor, "a shift to affect signals a shift from this body of work." (p. 206, italics in the original)

However, despite sharing this critique, some feminist scholars have found in the processual spirit of affect studies a promising matrix to further advance the feminist agenda. Probably a first important text due to its conciliatory spirit was the collection "Working with Affect in Feminist Readings. Disturbing differences" edited by Marianne Liljeström and Susanna Paasonen in 2010. In this book the suspicion about the ontological focus is manifested through chapters that aim to explore commonalities between the insights developed in affect theory and the feminist agenda operating under the poststructuralist logic and implementing qualitative methods, particularly those working with textual data. In the words of the editors "rather than to position considerations of materiality, affect and embodiment in opposition to textual analysis, the book investigates their interrelations as intimate co-dependence” (2010, p. 2). Two years later Carolyn Pedwell and Anne Whitehead (2012) put together a special issue in the journal Feminist Theory entitled "Affecting Feminism: Questioning of feeling in feminist theory", where the articles rely on a variety of feminist traditions to explore the ways in which the emotional dimension of life articulated in the social and public realms comes to be experienced inside gendered bodies. The contributions of that special issue explore in depth the implications of the intersection between affect and feminism with questions about the privilege of the subject, the epistemological implications, and the potential for social transformation. The approaches in this issue are closely related to the "public feelings" perspective, originally coined by Anne Cvetkovich (2012) but ever since used as a shared label by feminist theorists like Lauren Berlant and Kathleen Stewart to explore the emerging affective configurations that connect bodies and experiences in specific contexts.

Of particular interest in this intersection is the approach to science and technology of feminist scholars engaging with affect. Patricia Clough (2018) has recently described how feminist theorists like Luciana Parisi, Tiziana Terranova, Elizabeth Grosz, and Karen Barad have shifted the focus on theorizing the intricacies of human bodies and technologies: they "have contributed to moving feminist theory from epistemological concerns to addressing ontological ones, including the ontology of asubjective, nonconscious affect, and have thereby opened the study of bodies other than the human body" (Clough, 2018, p. 68). In this point the intersection between affect and feminism is closely related to another contemporary movement known as New Materialism. 
Finally, the rhetoric of affect has been used by Clare Hemmings (2011) to explain the way feminist scholars tell the story of feminism, as she argues, feminist narratives of progress, loss and return represent a political grammar of feminism that entails the idea of a shared Affective or emotional state. This Affective-epistemological reflection has also been taken by Prudence Chamberlain (2016, see also 2017) argues that the socalled fourth wave of feminism could be understood in terms of an "Affective temporality" that reframes the present by the immediacy of technology and creates affective communities able to connect historicity and past with the future, bringing new possibilities for feminist activism and theorization.

Now disability. Previous to the emergence of affect studies, disability studies had a history of challenging the medical and psychological discourses that pathologize and individualize disabilities. In response to this, disability scholars and allies have developed a variety of approaches to look at the political artefacts in which disability is embedded as well as the socio-historic context in which disabled bodies are featured as more or less capable. Having as a main concern to explore the capacities of bodies to affect and being affected, or what a body can do, the mutual interest between affect studies and disability studies came rather naturally.

Recently, Daniel Goodley, Kristy Liddiard and Katherine Runswick-Cole (2018), have explored some of the intersections of affect and critical disability studies. They propose that the first clear connection is what they call the emotional labour of disabled people. This emotional labour happens in the context of what they describe as a sort of ontological individuation, where the disabled condition is isolated and excluded by behaviours of non-disabled people that promote an ableist culture. This emotional labour, for example, is present when disabled people have to cope with the encounters of non-disabled people that navigate themselves based on social scripts that, for example, allow non-disabled people to ask highly personal questions or all kind of comments about disabled bodies. In addition to this, and drawing parallels with feminist theorist, Sara Ahmed and her concept of 'feminist killjoy', they argue for a crip politics and their commitment to resisting positions imposed by normative society. In their words, "Disabled people are similarly strangers at the neoliberal-able table that only recognizes self-sufficiency. (...) To be or become disabled is to work against a normative ableist culture that pursues its own happiness through a celebration of individual autonomy" (Goodley et al., 2018, p. 211). Finally, another theoretical commonality between affect and disability is the idea that a body's capacities is always contextual, and such capacities emerge from the specific configurations of resources articulated in specific contexts, thus the dis-ability becomes a specific arrangement between bodies 
and environments that call for asking who has the agency to reconfigure such relations and what is the agenda upon which this is being decided.

In a special issue on Affect and Subjectivity, disability theorist Akemi Nishida (2017) analyses what she calls the U.S. neoliberal public healthcare assemblage, where low paid women of colour provide care to disable people. Akemi explores the ways in which through repetition of certain practices and haptic connection, the relation between disabled and non-disabled bodies produces a sort of co-capacitation of both subjects. She develops the concept of "affective relationality" to explain that while some capacities are gained by disabled bodies through this healthcare system, the system is also played in a way that able bodies also gain some capacities like manipulation of time or income. In this dynamic disabled bodies are crucial to enable non-disabled bodies within a neoliberal assemblage of precarity.

The politics of what a body can do have been a central concern on this intersection between affect and disability. Some years ago, Jasbir Puar started a project to rethink disability based on some insights of affect theory (as well decolonial and queer theories) and given the current socio-political event like the war on Syria, or the healthcare policies in US, that willingly increase or decrease bodies capacities with political agendas. She proposed that:

A move from disability to debility - would not be to disavow the crucial political gains enabled by disability activists globally, but to invite a deconstruction of what ability and capacity mean, affective and otherwise, and to push for a broader politics of debility that destabilizes the seamless production of abled-bodies in relation to disability. (Puar, 2009, 166)

For Jasbir Puar, disability is not a fixed state, but it exists within an assemblage that promotes straightening capacities or the debilitation of bodies in specific geopolitical context historically situated. Disability production is embedded in a neo-colonial matrix where race, class and gender interconnect to produce disabilities with different potential for social action. Jasbir has recently put it this way: "when disability is perceived as the result of the exceptional accident or when its cause is unknown, reclaiming disability as a valuable, empowering difference may be more possible than when debilitation is caused by practices of global domination and social injustice" (Puar, 2017, 92).

While it is true that affect studies have been in dialogue with fields and disciplines as diverse as cinema studies, food studies, media, cultural geography, social psychology, sound studies, decolonial studies, etc., feminist theories and critical disability 
studies are of particular relevance to rethink and further advance the role of affect theories in the contemporary landscape of social theories and social sciences.

\section{Mainlands on the map}

Now, let's talk about our map. Exploring the intersection between affect and queer theories, Wen Liu proposes three different strains of queer affect: 'feeling down', which centres in the ways in which negative feelings are attached to and circulated around queer bodies; 'feeling backward', where scholars challenge the heteronormative structure of temporality that normalizes patterns of repetition and paths of becoming; and 'feeling machinic' where the focus is on body's capacities as an agentive matter that directly creates felt experience. Overall, Liu claims, these forms of queer affect expand the primary scales of analysis on the cultural, textual and bodily domains while disrupting assumptions about the circulation and materiality of feelings and porousness of bodies. Colin Ashley and Michelle Billies explore the shared space of affect and blackness. They challenge the normative uses of race generally associated to social constructions used to understand subjectivity and discipline, instead they want to move towards an understanding of the affective capacities of blackness as well as the affective capacities of racial production. To do so, Colin and Michelle engage in the exploration of what they call 'Black ontology' understood as the tension between Afro-Pessimism and Black Optimism. In their approach taking affective blackness seriously questions the idea of 'affect and race', modelling a focus on specific racial productions and capacities for their singular (complex, proliferating, historical, future-oriented) capacities.

Guillermina Altamonte explores the intersection between affect and labour studies. Drawing on Hardt and Negri, she explores the idea of affective labour, understood as production and manipulation of affects that is appropriated by capital. Then she explores feminist insights on the idea of reproductive labour and its racialized, classed and transnational configurations in order to understand capitalist labour markets. Finally, she reviews the work of influential author Arlie Hochschild and her notion of emotional labour referring to the provision of emotional responses especially in-service occupations. Altamonte's exploration of the intersection of affect and labour offers theoretical resources that help to better understand relations of inequality in contemporary late capitalism. In the same critical spirit to neoliberal capitalism, and to explain the relationship between affect and neuroscience and cognition Tony Sampson suggests that in the contemporary world we face two particular phenomena, on one hand the diminishment of mental capacities and in the other an imperceptible governing power taking over the nonconscious process. In his view, these two qualities of 
neoliberal capitalism raise a theoretical tension about the nature of the neurological nonconscious and its relationship with bodily and ultimately cognitive capacities. Relaying on Hayles, Tony explains how one way of understanding this neurological nonconscious is by reframing what cognition means, especially understood as cognition beyond the human brain and including existence of the non-cognitive congnition; the other theoretical alternative is the approach taken by new materialists to affect theories for whom the non-conscious is purely neurological.

Finally, Sandra Moyano develops the relationship between affect and art and literature by exploring the question of representation as a crucial aspect for the theoretical developments of both, affect and art and literature. According to Sandra, if we focus on the problem of representation, we can see how the developments in affect theory can be classified on two types, on one hand those who claim to remain "between representation" addressing affect as a process that exceeds cognition to look at how affects affect representation; and in the other hand, there are art and literary theorist exploring "beyond representation" and understanding affect as an autonomous force whose capacities go beyond its impact in cognition. On developing this analysis, Sandra goes to the core philosophical question of affect theory, the mediating nature of the ontologically diverse entity that affect is.

A final word to acknowledge the developments on affect theories that have taken place in the Spanish speaking world and that are not present in this special issue. As mentioned before this special issue is simultaneously published in English and Spanish to promote collaborations and the articulation of affect theories with the Spanish academia; however, affect theory is already happening in Spanish. It is necessary to acknowledge several authors here; in Argentina, Daniela Losiggio and Cecilia Macón (2017) regarding the politics of affect in Latin-America, as well as Ana Abramowski and Santiago Canevaro (2017) on affect, education and care in Argentina; in México, Helena López (2014) on affect and feminism, and Ana del Sarto (2012) on affect and precarious women and children subjectivity; in Chile, Cynthia Francica (2018) on literature community and friendship, to mention just a few amongst these already engaging with affect theory and to which this special issue is specially directed. Finally, thank you to those who helped on translating the articles in this special issue: Sandra Moyano, Nuria Sadurní, Bibi Calderon and Edwin Mayoral.

\section{References}

Abramowsky, Ana \& Canevaro, Santiago (2017). Pensar los afectos. Aproximaciones desde las ciencias sociales y las humanidades. Buenos Aires: Ediciones UNGS. 
Ahmed, Sara (2015). The Cultural Politics of Emotion. London: Routledge.

Bakko, Matthew \& Merz, Sibille (2015). Towards an Affective Turn in Social Science Research? Theorising Affect, Rethinking Methods and (Re)Envisioning the Social. Graduate fournal of Social Sciences, 11(1), 7-14.

Barad, Karen (2014). Diffracting Diffraction: Cutting Together-Apart. Parallax, 20(3), 168-187. https://doi.org/10.1080/13534645.2014.927623

Chamberlain, Prudence (2016). Affective temporality: towards a fourth wave. Gender \& Education, 28(3), 458-464. https://doi.org/10.1080/09540253.2016.1169249

Chamberlain, Prudence (2017). The Feminist Fourth Wave. Affective Temporality. London: Palgrave.

Clough, Patricia (2004). Future Matters: Techno- science, Global Politics, and Cultural Criticism. Social Text, 22(3), 1-23.

Clough, Patricia (2009). The New Empiricism Affect and Sociological Method. European fournal of Social Theory, 12(1), 43-61. https://doi.org/10.1177/1368431008099643

Clough, Patricia (2018). The User Unconscious. Minneapolis: Minessota University Press.

Cromby, John (2015). Feeling bodies: Embodying psychology. London, UK: Palgrave Macmillan.

Cvetkovich, Anne (2012). Depression. A public feeling. Durham: Duke University Press.

Del Sarto, Ana (2012). Los afectos en los estudios culturales latinoamericanos. Cuerpos y subjetividades en Ciudad Juárez. Cuadernos de Literatura, 32, 41-68. Recuperado a partir de https://revistas.javeriana.edu.co/index.php/cualit/article/view/4060

Ellis, Darren \& Tucker, Ian (2015). Social psychology of emotions. London, UK: Sage.

Enciso, Giazú \& Lara, Ali (2014). Emociones y ciencias sociales en el S. XX: la precuela del giro afectivo. Athenea Digital, 14(1), 263-288. https://doi.org/10.5565/rev/athenead/v14n1.1094

Fisher, Claire (2016). Feminist Philosophy, Pragmatism, and the "Turn to Affect": A Genealogical Critique. Hypatia, 31(4), 810-826. https://doi.org/10.1111/hypa.12296

Francica, Cinthya (2018). Comunidad, amistad y afecto en la literatura y las artes visuales argentinas durante la crisis de 2001. In Macarena Cordero Fernández, Pedro E. Moscoso-Flores \& Antonia Viu (Eds.), Rastros y gestos de las emociones. Desbordes disciplinarios (pp. 491-525). Santiago de Chile: Cuarto Propio.

Gibbs, Anna (2002). Disaffected. Fournal of Media and Cultural Studies, 16(3), 335-341. https://doi.org/10.1080/1030431022000018690

Goodley, Daniel; Liddiard, Kristy \& Runswick-Cole, Katherine (2018). Feeling disability: theories of affect and critical disability studies. Disability \& Society, 33(2), 197-217. https://doi.org/10.1080/09687599.2017.1402752

Hemmings, Claire (2011). Why Stories Matter: The Political Grammar of Feminist Theory. Durham: Duke University Press. 
Knudsen, Britta \& Stage, Carsten (2015). Affective Methodologies: Developing Cultural Research Strategies for the Study of Affect. London: Palgrave McMillan.

Koivunen, Anu (2010). An Affective Turn? Reimagining the subject of feminist theory. In Marianne Liljeström \& Susanna Paasonen (Eds.), Disturbing Differences: Working with Affect in Feminist Readings (pp. 8-28). London: Routledge.

Lara, Ali (2015). Teorias Afectivas Vintage. Apuntes sobre Deleuze, Bergson y Whitehead. Cinta de Moebio, 52, 17-36. http://dx.doi.org/10.4067/S0717$\underline{554 X 2015000100002}$

Lara, Ali (2017). Wine's time: Duration, Attunement and Diffraction. Subjectivity, 10(1), 104-122. https://doi.org/10.1057/s41286-016-0016-4

Lara, Ali (2018). Craving Assemblages: Consciousness and Chocolate Desire. Capacious, 1(2), 38-57. https://doi.org/10.22387/CAP2017.10

Lara, Ali \& Enciso, Giazú (2013). El giro afectivo. Athenea Digital, 13(3), 101-119. https://doi.org/10.5565/rev/athenead/v13n3.1060

Lara, Ali \& Enciso, Giazú (2014). Ciencia, teoría social y cuerpo en el giro afectivo: esferas de articulación. Quaderns de Psicologia, 16(2), 7-25. http://dx.doi.org/10.5565/rev/qpsicologia.1172

Lara, Ali, Liu, Wen, Ashley, Colin, Nishida, Akemi, Liebert, Rachel. \& Billis, Michel (2017). Affect \& Subjectivity. Subjectivity. 10, 30-43. https://doi.org/10.1057/s41286-016-0020-8

Leys, Ruth (2017). The Ascent of Affect. Genealogy and critique. London: The University of Chicago Press.

Liljeström, Marianne. \& Paasonen, Susanna (2010). Working with Affect in Feminist Readings. London: Routledge.

López, Helena (2014). Amociones, afectividad y deminismo. In, A. García \& O. Sabido (Eds.), Cuerpo y Afectividad en la Sociedad contemporánea (pp. 257-275).

México D. F: Universidad Autónoma Metropolitana.

Losiggio, Daniela \& Macón, Cecilia (2017). Afectos Politicos. Ensayos sobre actualidad. Buenos Aires: Miño y Dávila.

Martinez, Antar. \& Lara, Ali (2019). Affective modulation in positive psychology's regime of happiness. Theory \& Psychology, 29(3), 336-357.

https://doi.org/10.1177\%2F0959354319845138

Massumi, Brian (2015). Politics of affect. Malden, MA: Polity.

Meillassoux, Quientin. (2012). After Finitude. An essay on the necessity of contingency. London: Continuum.

Nishida, Akemi (2017). Relating through differences: disability, affective relationality and the U.S. public healthcare assemblage. Subjectivity, 10(1), 89-103. https://doi.org/10.1057/s41286-016-0018-2

Parisi, Luciana \& Goodman, Steve (2011). Mnemonic control. In P. T. Clough \& C. Willse (Eds.), Beyond Biopolitics: Essays on the governance of life and death (pp. 163-176). Durham: Duke University Press. 
Pedwell, Carolyn. \& Whitehead, Anne (2012). Affecting feminism: Questions of feeling in feminist theory. Feminist Theory, 13(2), 115-129. https://doi.org/10.1177\%2F1464700112442635

Protevi, John (2009). Political affect: Connecting the social and the somatic. Durham, NC: Duke University Press.

Puar, Jasbir (2009). Prognosis time: Towards a geopolitics of affect, debility and capacity. Women \& Performance: a Journal of Feminist Theory, 19, 161-172. https://doi.org/10.1080/07407700903034147

Puar, Jasbir (2017). The right to maim. Debility, Capacity, Disability. Durham: Duke University Press.

Rai, Amit (2018). Jugaad Time: Ecologies of Everyday Hacking in India. Durham: Duke University Press.

Seigworth, Gregory (2017). Capaciousness. Capacious: fournal for Emerging Affect Inquiry, 1(1), i-v. DOI: https://doi.org/10.22387/cap2017.7

Thrift, Nigel (2007). Non-representational theory: space, politics, affect. London: Routledge.

Vannini, Philip (2015). Non-Representational Methodologies. London: Routledge.

Wetherell, Margaret (2012). Affect and Emotion: A New Social Science Understanding. London: SAGE, Publications LTD.

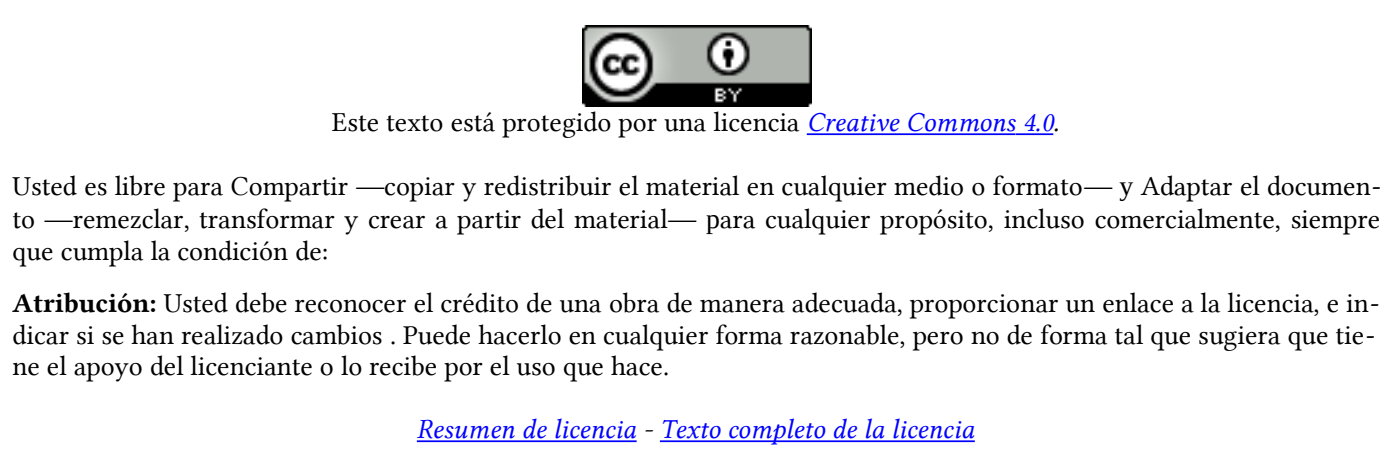

